\title{
CHOLESTEROL AND PROTEIN STUDIES IN EARLY STAGES OF TRAUMATIC PARAPLEGIA AND TETRAPLEGIA
}

\author{
By K. B. Edwards, B.Sc., H. Frankel, M.B., B.S., M.R.C.P., and \\ Sir Ludwig GuttmanN, C.B.E., M.D., F.R.C.P., F.R.C.S. \\ National Spinal Injuries Centre, Stoke Mandeville Hospital, \\ Aylesbury, England
}

TRAUMATIC paraplegia and tetraplegia following fractures and fracture-dislocations of the vertebral column is inevitably associated in the first instance with primary shock, severe local damage and profound changes of the function of the autonomic mechanisms. As a result of this disaster, homeostasis is thrown into chaos, especially in transection or severe incomplete lesions of the cervical cord, and the regulatory function of the nervous system in maintaining a suitable internal environment in these high lesions is greatly reduced. Therefore it was thought worth while to study the behaviour of serum proteins and cholesterol in relation to some basic haematology in the immediate and early stages of traumatic paraplegia and tetraplegia. Reports in the literature of similar comparative studies in acute traumatic lesions of the spinal cord are lacking but similar studies, including those of Woodford-Williams et al. (1962) have been performed in other types of afflictions. These authors examined the same variables in a series of elderly patients immediately after cardiac or cerebral infarction, surgical operations, and congestive heart failure.

Clinical Material. Twenty-six patients-2I male and 5 female-with spinal cord injuries as a result of vertebral fractures or fracture-dislocations were investigated, all of whom were admitted to the National Spinal Injuries Centre on or close to their date of injury. They were studied over a minimum period of six weeks and the chemical pathology due to subsequent urinary infection was also observed. The average age was 28 with limits ranging from I6 to 58 , and their injuries were classified according to the level of neurological lesions and further classified into complete or incomplete lesions.

The patients fell into the following categories:-

\section{TABLE I}

Figures in Brackets represent Associated Injuries

\begin{tabular}{|c|c|c|c|}
\hline Lesion level & Total number & Complete & Incomplete \\
\hline Cervical . & Io (6) & $8(5)$ & $2(\mathrm{I})$ \\
TI-T5 . & $2(\mathrm{I})$ & $2(\mathrm{I})$ & 0 \\
T6-TI2 . & $8(3)$ & $6(3)$ & 2 \\
Below TI2 & $6(2)$ & $3(2)$ & 3 \\
\hline
\end{tabular}


Even the cases with incomplete lesions had sustained severe neurological involvement, including one case with a fracture dislocation of $\mathrm{T}_{12} / \mathrm{LI}_{1}$, who eventually made a complete neurological recovery. The type of associated injury is shown in Table II.

TABLE II

Associated Injuries were Observed as Follows:-

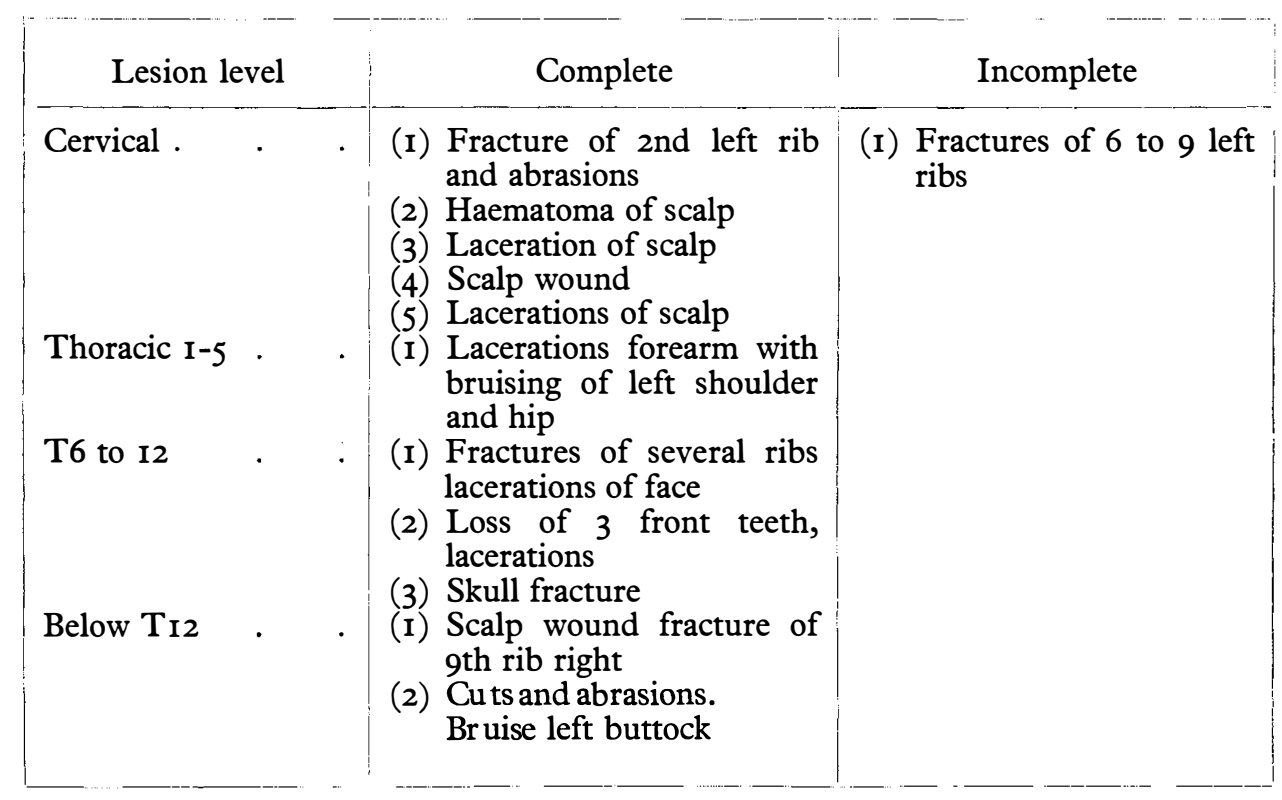

Procedure. Blood samples were taken from the patients immediately on arrival at the Centre and thereafter between 10 a.m. and 12 noon. Frequency of blood sampling was as follows: daily during the first week, three times in the second week at evenly spaced time intervals, twice in the third week and thereafter once weekly up to a minimum of six weeks.

Determinations and Methods. Determinations carried out were as follows:-

I. Erythrocyte sedimentation rate (E.S.R.).

2. Blood haemoglobin concentration $(\mathrm{Hb})$.

3. Packed cell volume (P.C.V.).

4. Serum cholesterol.

5. Total serum proteins.

6. Serum albumin.

7. Serum globulin with electrophoretic separation into alpha, beta, and gamma fractions.

8. Plasma fibrinogen.

\section{Methods:-}

I. E.S.R. was determined by Westergren method with reading at one hour.

2. Haemoglobin was assayed photometrically by an oxyhaemoglobin method. 
3. Packed cell volume (P.C.V.) was measured by centrifuging the sample in a Wintrobe tube at 3000 r.p.m. for one hour precisely.

4. Serum cholesterol was determined by the method of Webster (1962).

5. Total serum proteins were measured by the Biuret method using the reagent of Weichselbaum and a human crystalline albumin standard (Dade).

6. Serum albumin was assayed electrophoretically by the method of Webster (I963) using cellulose acetate strips.

7. Serum globulin derived by the difference between total serum protein and serum albumin concentrations. The relative concentrations of alpha, beta and gamma globulins were obtained by scanning the strip in a Joyce Chromoscan.

8. Plasma fibrinogen was determined by the Biuret method following prior treatment of the sample with thrombin.

All photometric measurements were made on a Unicam S.P. 600 instrument.

\section{RESULTS}

The results were examined from three standpoints. First the behaviour of all cases was considered; secondly the results in the three main anatomical divisions - cervical, thoracic and lumbar-were compared; thirdly, the results of patients who had associated injuries to their basic spinal cord injury were compared with those who had uncomplicated cord or cauda equina lesions.

(I) Erythrocyte Sedimentation Rate (E.S.R.) (Tables III and VI). Nearly all cases showed an increase in E.S.R. of moderate degree. This increase was most marked in the thoracic group but was also discernible in the cervical and lumbar groups, its sequence being thoracic, lumbar and cervical. All patients with associated injuries had a higher value.

\section{TABLE III}

Mean Highest Level for E.S.R. and Mean Initial Level and Fall of $\mathrm{Hb}$ and P.C.V. with Ranges

\begin{tabular}{|c|c|c|c|c|c|}
\hline \multirow{2}{*}{$\begin{array}{l}\text { Level of } \\
\text { lesion }\end{array}$} & \multirow{2}{*}{$\begin{array}{l}\text { E.S.R. mm. } \\
\text { Mean high } \\
\text { level }\end{array}$} & \multicolumn{2}{|c|}{ Haemoglobin g. $\%$} & \multicolumn{2}{|c|}{ P.C.V. \% } \\
\hline & & $\begin{array}{c}\text { Mean } \\
\text { initial } \\
\text { level }\end{array}$ & $\begin{array}{l}\text { Mean } \\
\text { change }\end{array}$ & $\begin{array}{l}\text { Mean } \\
\text { initial } \\
\text { level }\end{array}$ & $\begin{array}{l}\text { Mean } \\
\text { change }\end{array}$ \\
\hline Cervical & $\begin{array}{c}36 \\
(\mathrm{I} 2 \text { to } 6 \mathrm{I})\end{array}$ & $\begin{array}{c}\text { I } 4 \cdot 6 \\
(9 \cdot 7 \text { to } 16 \cdot 4)\end{array}$ & $\begin{array}{c}-0.7 \\
(-3.5 \text { to }+3 \cdot 7)\end{array}$ & $\begin{array}{c}4^{2} \\
(37 \text { to } 48)\end{array}$ & $(-8$ to +5$)$ \\
\hline Thoracic & $\begin{array}{l}74 \\
\text { (30 to II } 4)\end{array}$ & $\begin{array}{c}\text { I2.8 } \\
(\mathrm{IO} \cdot 2 \text { to } \mathrm{I} 4 \cdot 5)\end{array}$ & $\begin{array}{c}-\mathbf{I} \cdot \mathbf{I} \\
(-2 \cdot 9 \text { to }+\mathbf{I} \cdot 6)\end{array}$ & $\begin{array}{c}3^{8} \\
(3 \mathrm{I} \text { to } 4 \mathrm{I})\end{array}$ & $\begin{array}{c}-4 \\
(-6 \cdot 5 \text { to }+3)\end{array}$ \\
\hline Lumbar & $\begin{array}{c}56 \\
(42 \text { to } 70)\end{array}$ & $\begin{array}{c}13.6 \\
(10.4 \text { to } 15.7)\end{array}$ & $\begin{array}{c}-\mathrm{I} \cdot 8 \\
(-2 \cdot 2 \text { to }+\mathrm{I} \cdot 0)\end{array}$ & $\begin{array}{c}39 \\
(31 \text { to } 45)\end{array}$ & $\left(-\frac{-3}{6}\right.$ to o $)$ \\
\hline
\end{tabular}


(2) Haemoglobin $(\mathrm{Hb})$ (Tables III and VI). A minority of patients (I2 out of 26) showed a slight fall in $\mathrm{Hb}$ concentration in the first few days of injury, the fall being most marked in the lumbar group.

The mean initial level for the cervical group ( $14.6 \mathrm{~g}$.) was distinctly higher than the mean initial levels of the other two groups and that of the thoracic group was particularly low (12.8 g.).

TABLE IV

Mean Initial Levels and Maximum Change of Serum Cholesterol, Total Serum Proteins, Serum Albumin and Plasma Fibrinogen with Range of Values

\begin{tabular}{|c|c|c|c|c|}
\hline \multirow{2}{*}{ Level of lesion } & \multicolumn{2}{|c|}{$\begin{array}{l}\text { Serum cholesterol } \\
(\mathrm{mg} . \%)\end{array}$} & \multicolumn{2}{|c|}{$\begin{array}{l}\text { Total serum proteins } \\
(\mathrm{g} . \%)\end{array}$} \\
\hline & $\begin{array}{l}\text { Mean initial } \\
\text { level }\end{array}$ & Mean change & $\begin{array}{l}\text { Mean initial } \\
\text { level }\end{array}$ & Mean change \\
\hline Cervical & $\begin{array}{c}172 \\
\text { (I25 to } 197\end{array}$ & $\begin{array}{c}-26 \\
(-56 \text { to }+16)\end{array}$ & $\begin{array}{c}6 \cdot 51 \\
(5 \cdot 38 \text { to } 7 \cdot 08)\end{array}$ & $\begin{array}{c}-0.38 \\
(-\mathrm{I} \cdot 03 \text { to }+0.64)\end{array}$ \\
\hline Thoracic & $\begin{array}{c}\text { I } 55 \\
\text { (I30 to I95) }\end{array}$ & $\begin{array}{c}-10 \\
(-32 \text { to }+34)\end{array}$ & $\begin{array}{c}6 \cdot 76 \\
(6 \cdot 26 \text { to } 7 \cdot 20)\end{array}$ & $\begin{array}{c}-0.3 \mathrm{I} \\
(-0.88 \text { to }+0.8 \mathrm{I})\end{array}$ \\
\hline Lumbar . & $\begin{array}{c}\text { I6I } \\
(\text { II } 5 \text { to } 208)\end{array}$ & $\begin{array}{c}-14 \\
(-70 \text { to }+25)\end{array}$ & $\begin{array}{c}7 \cdot 17 \\
(6 \cdot 41 \text { to } 7 \cdot 63)\end{array}$ & $\begin{array}{c}-0.55 \\
(-0.98 \text { to }+0.22)\end{array}$ \\
\hline \multirow{2}{*}{ Level of lesion } & \multicolumn{2}{|c|}{$\begin{array}{l}\text { Serum albumin } \\
(\mathrm{g} . \%)\end{array}$} & \multicolumn{2}{|c|}{$\begin{array}{l}\text { Plasma fibrinogen } \\
(\mathrm{mg} . \%)\end{array}$} \\
\hline & $\begin{array}{l}\text { Mean initial } \\
\text { level }\end{array}$ & Mean change & $\begin{array}{l}\text { Mean initial } \\
\text { level }\end{array}$ & Mean change \\
\hline Cervical & $\begin{array}{c}3 \cdot 29 \\
(2 \cdot 48 \text { to } 3 \cdot 6 I)\end{array}$ & $\begin{array}{c}-0.49 \\
(-\mathrm{I} \cdot \mathrm{I} 0 \text { to }+0.09)\end{array}$ & $\begin{array}{c}353 \\
\text { (I } 50 \text { to } 550)\end{array}$ & $\begin{array}{c}+\mathrm{I} 40 \\
(+30 \text { to } 240)\end{array}$ \\
\hline Thoracic & $\begin{array}{c}3 \cdot 32 \\
(2 \cdot 94 \text { to } 3 \cdot 60)\end{array}$ & $\begin{array}{c}-0.6 \mathrm{I} \\
(-0.92 \text { to }-0.17)\end{array}$ & $\begin{array}{c}420 \\
\text { (250 to } 570)\end{array}$ & $\begin{array}{c}+130 \\
(-10 \text { to }+400)\end{array}$ \\
\hline Lumbar . & $\begin{array}{c}3.57 \\
(3 \cdot 39 \text { to } 3 \cdot 90)\end{array}$ & $\begin{array}{c}-0.68 \\
(-0.98 \text { to }-0.36)\end{array}$ & $\begin{array}{c}352 \\
(250 \text { to } 500)\end{array}$ & $\begin{array}{c}+192 \\
(140 \text { to }+250)\end{array}$ \\
\hline
\end{tabular}

Little difference was seen initially between the patients with associated injuries and the remainder with the exception of the thoracic group where a greater fall was demonstrable.

(3) Packed Cell Volume (P.C.V.) (Tables III and VI). Results in the thoracic and lumbar groups were similar and showed no marked trends. 
In the cervical group the mean initial P.C.V. was higher (42 as compared with 38 for the thoracic group and 39 for the lumbar group). The P.C.V. in the cervical was found for the most part to run parallel with the haemoglobin concentration during the first few days of injury. The associated injury group demonstrated a greater fall than the group with uncomplicated cord lesions and here again this difference was particularly marked in the thoracic group.

\section{SERUM CHOLESTEROL}

CERVICAL GROUP

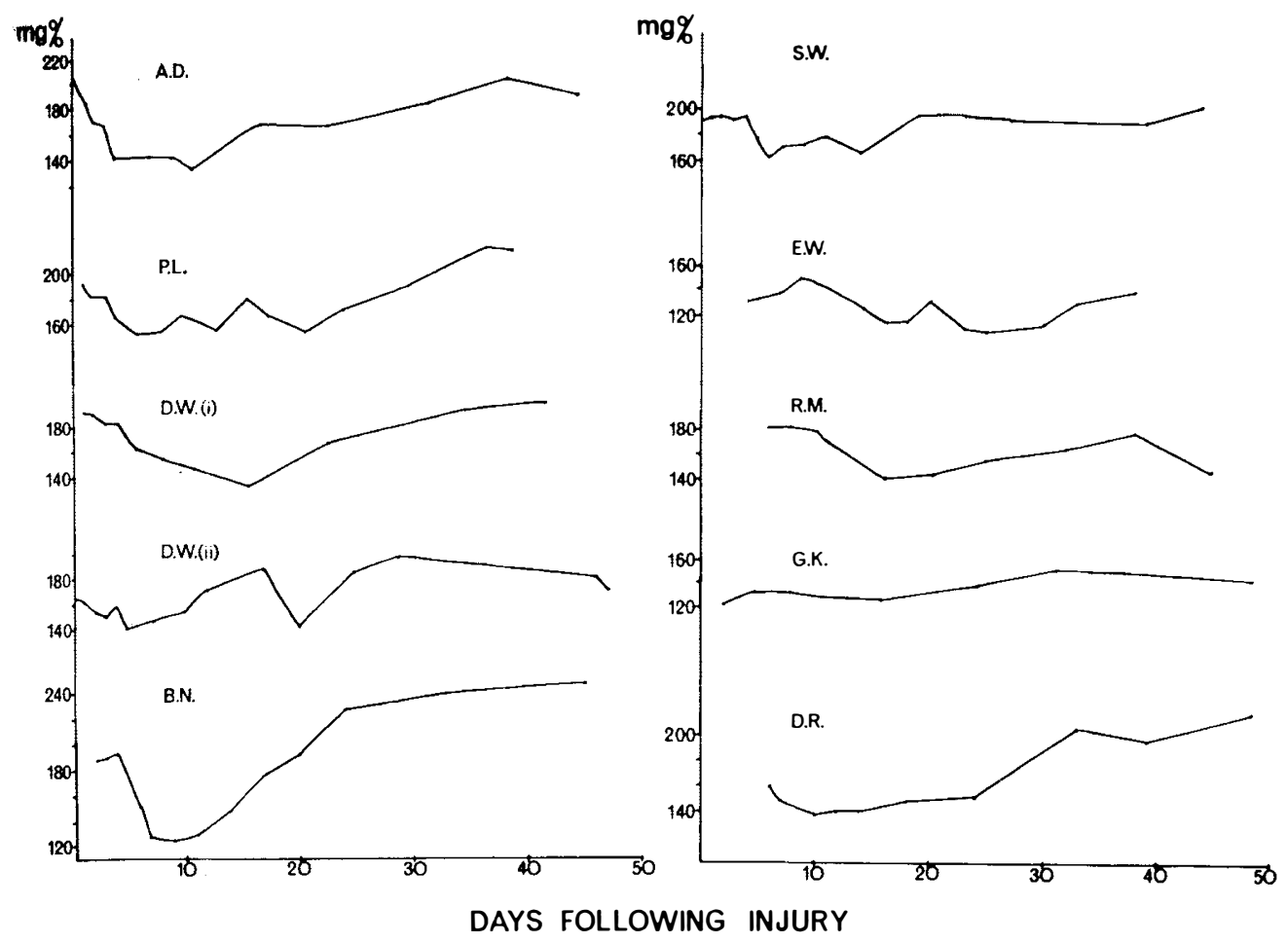

FIG. I

(4) Serum Cholesterol (Tables IV and VI). During the first few days over half the total number of cases showed a fall below the initial level in serum cholesterol concentration. This fall was moderate in degree. The cervical group behaved differently from the thoracic and lumbar groups in that both the incidence and the degree of fall were greater, as shown graphically in Figure I. Final serum cholesterol values in excess of the central values were seen in all groups. No significant difference was noted between the associated and nonassociated injury groups.

(5) Total Serum Proteins (Tables IV and VI). A slight fall in concentration was noted in most cases though its mean value did not exceed $0.6 \mathrm{~g}$. Results in 
the cervical and thoracic groups were similar, but the lumbar group demonstrated both a higher mean value and a greater degree of fall $(7.17 \mathrm{~g}$. and $0.55 \mathrm{~g}$. respectively). This is in accordance with previous observations (Guttmann, I945, I953; Robinson, I954).

\section{TABLE V}

Relative Concentrations of Albumin and Component Globulins expressed as Percentage of Total Protein Concentration. Ranges are in brackets

\begin{tabular}{|c|c|c|c|c|}
\hline \multirow{2}{*}{ Level of lesion } & \multicolumn{2}{|c|}{ Albumin } & \multicolumn{2}{|c|}{ Alpha I } \\
\hline & Initial & Mean change & Initial & Mean change \\
\hline Cervical . & $\begin{array}{c}5 \mathrm{I} \\
(43 \text { to } 58)\end{array}$ & $\begin{array}{c}-5 \\
(-10 \text { to }-2)\end{array}$ & $\begin{array}{c}4 \cdot 5 \\
(I \cdot 6 \text { to } 7 \cdot 6)\end{array}$ & $\begin{array}{c}\mathrm{I} \cdot 0 \\
(-\mathrm{I} \cdot 4 \text { to } 5 \cdot 0)\end{array}$ \\
\hline Thoracic & $\begin{array}{c}49 \\
(44 \text { to } 57)\end{array}$ & $\begin{array}{c}-7 \\
(-18 \text { to }-3)\end{array}$ & $\begin{array}{c}5 \cdot 4 \\
(1 \cdot 6 \text { to } 8 \cdot 5)\end{array}$ & $\begin{array}{c}2 \cdot 2 \\
(-\mathbf{I} \cdot 5 \text { to } 5 \cdot 8)\end{array}$ \\
\hline Lumbar . & $\begin{array}{c}50 \\
(47 \text { to } 54)\end{array}$ & (o to $\left.\frac{-5}{-10}\right)$ & $\left(3 \cdot 6^{4 \cdot 9}\right.$ to $\left.6 \cdot 8\right)$ & $\begin{array}{c}1 \cdot 0 \\
(+0 \cdot 1 \text { to } 2 \cdot 4)\end{array}$ \\
\hline \multirow[t]{2}{*}{ Level of lesion } & \multicolumn{2}{|c|}{ Alpha II } & \multicolumn{2}{|c|}{ Total alpha } \\
\hline & Initial & Mean change & Initial & Mean change \\
\hline Cervical . & $\begin{array}{c}\text { I5.5 } \\
(12.9 \text { to } 19.4)\end{array}$ & $\begin{array}{c}4 \cdot 2 \\
(0 \text { to } 13 \cdot 0)\end{array}$ & $\begin{array}{c}20 \cdot I \\
(15 \cdot 6 \text { to } 27 \cdot 0)\end{array}$ & $\begin{array}{l}5 \cdot 2 \\
(0 \cdot 1 \text { to } 15 \cdot 8)\end{array}$ \\
\hline Thoracic & $\begin{array}{c}\text { I } 5 \cdot 4 \\
(\mathrm{II} \cdot 6 \text { to } 2 \mathrm{I})\end{array}$ & $\begin{array}{c}5.0 \\
(-0.4 \text { to I6.7) }\end{array}$ & $\begin{array}{c}20 \cdot 8 \\
(13 \cdot 2 \text { to } 29 \cdot 4)\end{array}$ & $\begin{array}{c}7 \cdot 2 \\
(0 \text { to }+2 I \cdot 2)\end{array}$ \\
\hline Lumbar . & $\begin{array}{c}15 \cdot I \\
(13 \cdot 6 \text { to } 2 I \cdot 2)\end{array}$ & $(-4 \cdot 6$ to $+12 \cdot 3)$ & $\begin{array}{c}20 \cdot 0 \\
(17 \cdot 0 \text { to } 28 \cdot 0)\end{array}$ & $(-4 \cdot 0$ to $+12 \cdot 3)$ \\
\hline \multirow[t]{2}{*}{ Level of lesion } & \multicolumn{2}{|c|}{ Beta } & \multicolumn{2}{|c|}{ Gamma } \\
\hline & Initial & Mean change & Initial & Mean change \\
\hline Cervical . & $\begin{array}{c}\text { I } 3 \cdot \text { I } \\
(\text { II } 4 \text { to I6 } 6)\end{array}$ & $\begin{array}{c}0.9 \\
(-\mathrm{I} \cdot 7 \text { to } 3 \cdot 3)\end{array}$ & $\begin{array}{c}\text { I6.2 } \\
\left(13 \cdot 7^{\text {to }} \mathrm{I} 8 \cdot 7\right)\end{array}$ & $\begin{array}{c}-0.6 \\
(-6 \cdot 5 \text { to }+3 \cdot 3)\end{array}$ \\
\hline Thoracic & $\begin{array}{c}13 \cdot 8 \\
(\mathrm{II} \cdot 7 \text { to } \mathrm{I} 8 \cdot 8)\end{array}$ & $\begin{array}{c}0.7 \\
(-3.5 \text { to }+6.0)\end{array}$ & $\begin{array}{c}16 \cdot 2 \\
(10 \cdot 3 \text { to } 21 \cdot 6)\end{array}$ & $\begin{array}{c}-0 \cdot 7 \\
(-4 \cdot 7 \text { to }+2 \cdot 7)\end{array}$ \\
\hline Lumbar . & $\begin{array}{c}12 \cdot 9 \\
(\text { II } 6 \text { to } 14 \cdot 3)\end{array}$ & $\begin{array}{c}0.6 \\
(-3.9 \text { to }+4.4)\end{array}$ & $\begin{array}{c}15 \cdot 7 \\
(6 \cdot 8 \text { to } 20 \cdot 3)\end{array}$ & $\begin{array}{c}0 \cdot 7 \\
(-\mathbf{I} \cdot 7 \text { to }+2 \cdot 9)\end{array}$ \\
\hline
\end{tabular}


The associated injury group, however, demonstrated a greater degree of fall than the uncomplicated group, the difference being most noticeable in the cervical group.

(6) Serum Albumin (Tables IV, V, VI and VII). This constituent showed a fall in almost all the cases. The fall in thoracic and lumbar groups was only slightly more marked than in the cervical group within the first Io days of injury (I7.5 per cent. as compared with 19 and 19.5 per cent. respectively) Table VII.

TABLE VI

Comparison Results of Associated Cord Injury and Non-associated Cord Injury Patients (A.I =Associated Injury, Nil=Uncomplicated Injury

\begin{tabular}{|c|c|c|c|c|c|c|c|c|}
\hline \multirow{2}{*}{ Assay } & \multicolumn{2}{|c|}{ All groups } & \multicolumn{2}{|c|}{ Cervical } & \multicolumn{2}{|c|}{ Thoracic } & \multicolumn{2}{|c|}{ Lumbar } \\
\hline & A.I. & Nil & A.I. & Nil & A.I. & Nil & A.I. & Nil \\
\hline $\begin{array}{l}\text { E.S.R. } \\
\text { Mean highest } \\
\text { result }\end{array}$ & 57 & 52 & 46 & 27 & 85 & 66 & 66 & $5 \mathrm{I}$ \\
\hline $\begin{array}{l}\text { Haemoglobin. } \\
\text { Mean initial } \\
\text { result and mean } \\
\text { change, g. } \% .\end{array}$ & $\begin{array}{r}\mathrm{I} 3 \cdot 7 \\
\mathrm{I} \cdot 3\end{array}$ & $\begin{array}{r}\mathrm{I} 3 \cdot 8 \\
-\mathrm{I} \cdot \mathrm{I}\end{array}$ & $\begin{array}{r}\mathrm{I} 4.2 \\
-0.8\end{array}$ & $\begin{array}{r}\mathrm{I} 4.8 \\
-0.8\end{array}$ & $\begin{array}{r}12 \cdot 7 \\
-2 \cdot 2\end{array}$ & $\begin{array}{r}12 \cdot 8 \\
--0 \cdot 6\end{array}$ & $\begin{array}{r}13 \cdot 2 \\
-I \cdot 6\end{array}$ & $\begin{array}{r}13 \cdot 8 \\
-2 \cdot 0\end{array}$ \\
\hline $\begin{array}{l}\text { P.C.V.\%. } \\
\text { Mean initial } \\
\text { level and mean } \\
\text { change }\end{array}$ & $\begin{array}{r}40 \cdot I \\
-4 \cdot 6\end{array}$ & $\begin{array}{r}39 \cdot 7 \\
-2 \cdot 8\end{array}$ & $\begin{array}{r}* 42 \\
-4 \cdot 0\end{array}$ & $\begin{array}{r}42 \\
-3 \cdot 8\end{array}$ & $\begin{array}{r}37 \\
--6 \cdot 3\end{array}$ & $\begin{array}{r}38 \\
-\mathrm{I} \cdot 5\end{array}$ & $\begin{array}{r}4 I \\
-3 \cdot 0\end{array}$ & $\begin{array}{r}39 \\
-3 \cdot 3\end{array}$ \\
\hline $\begin{array}{l}\text { Serum } \\
\text { cholesterol. } \\
\text { Mean initial } \\
\text { level and change, } \\
\text { mg. } \%\end{array}$ & $\begin{array}{r}\mathrm{I} 6 \mathrm{I} \\
-\mathrm{I} 7\end{array}$ & $\begin{array}{r}\text { I66 } \\
-\mathrm{I} 7\end{array}$ & $\begin{array}{r}166 \\
-22\end{array}$ & $\begin{array}{r}185 \\
-27\end{array}$ & $\begin{array}{l}\text { I } 42 \\
-9\end{array}$ & $\begin{array}{l}\text { I63 } \\
-8\end{array}$ & $\begin{array}{r}181 \\
-13\end{array}$ & $\begin{array}{l}\text { I5I } \\
-4\end{array}$ \\
\hline $\begin{array}{l}\text { Total serum } \\
\text { proteins. } \\
\text { Mean initial level } \\
\text { and change, g. } \%\end{array}$ & $\begin{array}{r}6 \cdot 77 \\
-0.52\end{array}$ & $\begin{array}{r}6 \cdot 74 \\
-0.36\end{array}$ & $\begin{array}{r}6 \cdot 74 \\
-0.48\end{array}$ & $\begin{array}{r}6.62 \\
-0.34\end{array}$ & $\begin{array}{r}6.94 \\
-0.57\end{array}$ & $\begin{array}{r}6 \cdot 66 \\
-0 \cdot 11\end{array}$ & $\begin{array}{r}7.50 \\
-0.63\end{array}$ & $\begin{array}{r}7.00 \\
-0.51\end{array}$ \\
\hline $\begin{array}{l}\text { Serum albumin. } \\
\text { Mean initial level } \\
\text { and change, g. } \%\end{array}$ & $\begin{array}{r}3.31 \\
-0.58\end{array}$ & $\begin{array}{r}3.44 \\
-0.54\end{array}$ & $\begin{array}{r}3.17 \\
-0.42\end{array}$ & $\begin{array}{r}3.48 \\
-0.49\end{array}$ & $\begin{array}{r}3.34 \\
-0.79\end{array}$ & $\begin{array}{r}3.30 \\
-0.52\end{array}$ & $\begin{array}{l}3 \cdot 70 \\
0.75\end{array}$ & $\begin{array}{r}3.60 \\
-0.64\end{array}$ \\
\hline $\begin{array}{l}\text { Plasma fibrinogen } \\
\text { Mean level and } \\
\text { change, mg. } \% \text {. }\end{array}$ & $\begin{array}{r}370 \\
+\quad 170\end{array}$ & $\begin{array}{r}380 \\
+\quad 170\end{array}$ & $\begin{array}{r}390 \\
+150\end{array}$ & $\begin{array}{r}300 \\
+150\end{array}$ & $\begin{array}{r}370 \\
+210\end{array}$ & $\begin{array}{r}450 \\
+150\end{array}$ & $\begin{array}{r}340 \\
+\quad 170\end{array}$ & $\begin{array}{r}360 \\
+210\end{array}$ \\
\hline
\end{tabular}

* One patient not admitted until the fourth day after injury was not included in this group. 
There was also no significant difference between the associated and non-associated injury groups as a whole, though a difference was seen in the thoracic group.

(7) Serum Globulin (Table V). A slight rise in serum globulin was seen in most cases nearly concomitant with the serum albumin loss. Electrophoretic analyses showed the rise to be mainly in the alpha fraction, as previously found in this Centre by Robinson (1954). However, while the alpha globulin increased by 28 per cent. and the beta globulin by 6 per cent., the gamma fraction decreased by I per cent.

\section{TABLE VII}

Changes of Serum Albumin within the First Ten Days of Injury Results are expressed in Grams \%

\begin{tabular}{|c|c|c|c|}
\hline $\begin{array}{c}\text { Days following } \\
\text { injury }\end{array}$ & Cervical & Thoracic 6-I2 & Lumbar \\
\hline I & 3.52 & 3.40 & 3.62 \\
2 & 3.39 & 2.82 & 3.53 \\
3 & 3.23 & 3.00 & 3.37 \\
4 & 3.06 & 2.99 & 3.17 \\
5 & 2.99 & 2.82 & 3.14 \\
6 & 2.92 & 2.83 & 2.84 \\
7 & 2.63 & 2.79 & 3.11 \\
8 & 3.13 & 2.82 & 2.82 \\
9 & 2.60 & 2.76 & 2.92 \\
I0 & 2.90 & 2.75 & 2.91 \\
\hline
\end{tabular}

(8) Plasma Fibrinogen (Tables IV and VI). A slight initial rise was seen in most cases. The cervical and thoracic groups were similar but the rise in the lumbar group was greatest. No significant difference was seen between the associated injury and non-associated injury groups. Table VI demonstrates the comparative results obtained in associated cord injuries and non-associated cord injuries.

\section{DISCUSSION}

The results obtained mainly conform to the established pattern of protein, E.S.R. and plasma fibrinogen behaviour in primary shock, and it does not appear that the complication of neurological damage causes any particular biochemical abnormality.

Thus the rise in E.S.R. in the early days of injury is seen in many types of afflictions of both infective and traumatic origin. The observation of Cantarow and Trumper (1962) that a relative increase in E.S.R. is paralleled by an increase in plasma fibrinogen is on the whole confirmed by the results obtained in this series. The same authors postulate that an increase in plasma fibrinogen and the globulin fractions cause an increase in the sedimentation rate of red cells.

A fall in haemoglobin concentration in the first few days following trauma 
has been described by Barr and Topley (I956) and the present results are in agreement with their findings. However, the mean initial haemoglobin concentration was found to be higher in our cervical group as compared with the thoracic and lumbar series. This was associated with relatively higher values for P.C.V. in the cervical series. The obvious explanation of this difference could be found in the fact that patients with cervical injuries, are not as a rule, associated with such severe additional injuries as fractures of ribs, haemothorax or fractures of long bones, as is not infrequently the case in thoracic and lumbar cord injuries. However, the question arises how far the relative haemoconcentration in the stage of spinal shock following traumatic tetraplegia may be due to the paralytic vasodilatation which occurs over practically the whole of the body as a result of the interruption of the vaso-constrictors. The resulting sudden decrease of tone in the vascular wall may lead to increased permeability of the vascular wall and consequently to extravasation of fluid into the tissues and manifestation of oedema. Further studies on blood volume and electrolytes will be necessary to substantiate this hypothesis.

Changes in serum cholesterol concentration in shock have not been much commented upon but falls have been noted in fasting and certain infections, post-operatively and after attacks of coronary thrombosis. These findings are quoted by Bloor (1943), Man et al. (1946), Bjork et al. (1957) and Dodds and Mells (1959). The mean initial levels were rather low-a result in line with the work of Stoker et al. (1966) that both normal and abnormal subjects sustained a reduction in serum cholesterol concentration on changing from a vertical to a horizontal position of an order of 13 per cent.

Our cervical group have a higher mean initial level than the thoracic and lumbar groups and show a greater fall than the other two groups. In trying to explain the greater fall in the cervical patients it may first be remembered that cholesterol in serum derives from two main sources, namely, cholesterol absorbed from the gut (exogenous) and cholesterol synthesised by the liver from acetate residues (endogenous). It is probable that endogenous cholesterol accounts for over one half of this compound's concentration in blood serum.

The traumatic paraplegic and tetraplegic may suffer in the initial stages following injury a loss of cholesterol on two counts. First the decrease in his dietary intake during the first period of injury results in a reduced cholesterol intake and consequent reduced absorption from the gut. This is particularly true in the tetraplegic, due to his respiratory embarrassment as a result of the paralysis of his respiratory muscles and, furthermore, his difficulty in masticating properly, as a result of the paralytic vasodilatation leading to swelling of the mucosa and consequent blockage of the nasal air passages (Guttmann's sign). The dietary insufficiency may well have the effect that the acetate residues, upon which the liver depends for cholesterol synthesis, may be in short supply, since these residues derive from catabolism of dietary carbohydrate, fat and certain unessential amino acids. In this way a reduction of serum cholesterol concentration in these high cord lesions during the early days of injury could well be explained.

Secondly, one should not rule out some short-term impairment of the function of the liver itself in the stage of spinal shock of cord lesion above $\mathrm{T}_{5}$ and particularly cervical cord injuries, in view of the fact that in addition to the functional loss of the segmental innervation of the liver the whole sympathetic 
innervation is suddenly cut off. Further studies will be necessary to clarify this point.

Many workers have recorded changes in the serum proteins following injury, e.g., Cuthbertson and Tompsett (1935), Guttmann (1945, I953), Vaughan et al. (1946), Robinson (1954), Gillette et al. (1958).

Our present results confirm the general conclusions of these workers in that there is in most cases an initial loss of serum albumin possibly due to impaired liver function following trauma. The albumin/globulin ratio is often inverted and the albumin loss is accompanied by a globulin increase notably in the alpha fraction. This fact is notably established by the observation that in all groups the mean percentage albumin loss and the mean percentage total alpha globulin gain are almost identical.

In the few cases where infection set in at a later stage, the biochemical picture was almost identical to that seen in the first few days of injury, i.e. increased E.S.R. and plasma fibrinogen levels together with the serum protein changes described above. The cholesterol level was also reduced.

The classification of the patients into those with associated injuries and those without further underlines the expected result that a multiplicity of injuries of serious degree results in a more acute bodily response as indicated in all the parameters examined than when the physical damage is less severe. This tendency is most marked in the thoracic group where the difference is clearly delineated. Thus haemoglobin fall, E.S.R. increase and P.C.V. decrease are all apparent as is the rise in plasma fibrinogen concentration which is frequently associated with a raised E.S.R., a point already mentioned above. Two of the three lower thoracic cases had respectively fractured ribs and a fractured skull, apart from bruises in the soft tissues-injuries eminently able to account for the results shown and demonstrating the classical responses to severe trauma.

The cholesterol values are found to be of much the same order in both associated injury and uncomplicated groups, with the exception of the lumbar group (see Table VI), indicating that although slight falls of serum cholesterol have been demonstrated in a variety of conditions, including cardiac infarction and minor surgery, acute changes in serum cholesterol do not necessary constitute an essential part of the body's response to acute trauma. Serum proteins again conform to the general pattern met in response to injury. In cases where the trauma is most severe, the reduction of the total serum protein stemming mainly from a loss of serum albumin is usually very marked and this is demonstrated here.

The associated injury cases show a notable fall in the albumin fraction as compared with those cases who did not sustain other injury, and this fall is most pronounced in the thoracic and lumbar groups where the associated injuries were most severe.

\section{SUMMARY}

Changes in serum cholesterol in relation to E.S.R., Hb, P.C.V., plasma, fibrinogen, serum proteins have been studied in 26 acute traumatic paraplegic and tetraplegic patients.

In general the results are in agreement with those of other workers who have studied the variations of these components in other types of trauma, such as 
major and minor surgery, accidents, cardiac infarction and congestive heart failure. A relative haemoconcentration was found in traumatic tetraplegics and its mechanism is discussed.

The contrasted findings in three main anatomical groups, cervical, thoracic and lumbar, show little difference except in the case of the serum cholesterol values. Here the cervical group shows a greater fall than do the other two during the first few days of injury. Possible explanations of this finding are discussed.

It was found that patients with associated injuries showed a more marked response than those with uncomplicated spinal cord injury in nearly all the parameters examined.

\section{ACKNOWLEDGEMENT}

This study has been carried out with the aid of a grant to one of us (L. G.) from the Medical Research Council, to whom the authors are greatly indebted.

\section{REFERENCES}

BarR, S. \& Topley, E. (1956). Acta med. scand. 153, 3 I9.

BJorCK, G., BlondQuist, G. \& Sievers, J. (1957). Acta med. scand. 1 56, 493.

Blour, W. R. (1943). Biochemistry of the Fatty Acids, pp. I53 and I72. New York: Renihold Publishing Corporation.

Cantarow, A. \& Trumper, M. (I962). Clinical Biochemistry, p. I5I. Philadelphia: W. B. Saunders.

Cuthbertson, D. P. \& Tompsett, S. L. (1935). Br. F. exp. Path. 16, 47 I.

DodDs, C. \& Mills, G. L. (I959). Lancet, I, I I60.

Gillette, R. W., Mansberger, A. R., Oppenheimer, J. H., Caldwell, B. F. \& Neff, E. C. (1958). Surgery, 43, 745 .

Guttmann, L. (1945). Med. Times, N.Y., 73, 318.

GuttmanN (1953). History of the Second World War, vol. Surgery, p. 422. London: H.M. Stationery Office.

Man, E. B., Bettcher, P. G., Camerson, C. M. \& Peters, J. P. (1946). F. clin. Invest. 25, 701 .

Robinson, R. (I954). Proc. R. Soc. Med. 47, I Io9.

StOKER, D. J., WyNNE, V. \& RoberTson, G. (I966). Br. med. f. I, 336.

Vaughan, J., Thompson, M. \& Dyson, M. (I946). F. Path. Bact. 58, 749.

Webster, D. (1963). Clinica chim. Acta, 8, 19-25.

Webster, D. (1962). Clinica chim. Acta, 7, 277.

Weichselbaum, T. E. (1946). Am. F. clin. Path. Tech. 10, 40.

Woodford-Williams, E., Webster, D., LANDless, B. \& HerRiott, S. (1962). Symposium on Medical and Chemical Aspects of Ageing, p. 374. Columbia University Press. 